\title{
OTR9. PADRONIZAÇÃO DA TÉCNICA DE NEUTRALIZAÇÃO EM PLACA DE 96 POÇOS PARA AVALIAR A IMUNOGENICIDA- DE DA CAXUMBA EM VACINA COMBINADA.
}

Emily Hime Miranda ${ }^{1}$; Stephanie Almeida da Silva ${ }^{1}$; José Henrique Rezende Linhares $^{1}$; Vanessa de Oliveira Santos ${ }^{1}$; Renata de Carvalho Pereira ${ }^{1}$; Kátia Paulino Ribeiro de Souza ${ }^{1}$; Sheila Maria Barbosa de Lima ${ }^{1}$; Érika Martins de Carvalho².

${ }^{1}$ Biomanguinhos;

${ }^{2}$ Farmanguinhos.

INTRODUÇÃO A caxumba é uma doença infecto-contagiosa imunoprevenível por vacinação. A imunogenicidade vacinal é avaliada através de testes sorológicos. $\mathrm{O}$ Teste de Neutralização (PRNT) apresenta vantagens frente a outros testes por ser mais específico na detecção de anticorpos neutralizantes. O mesmo apresenta morosidade para a obtenção de um resultado, como também variabilidade se as etapas do processo e critérios de aceitação não estiverem definidos.

OBJETIVO $\mathrm{O}$ objetivo deste trabalho foi avaliar a interferência do tempo de neutralização na ligação vírus - soro; determinar o melhor ponto de corte (cut-off) do teste e estabelecer critérios de aceitação em relação à faixa de variação do vírus e dos soros padrões após o estabelecimento das condições analíticas.

METODOLOGIA Inicialmente, o vírus estoque foi diluído em placas de 96 poços, mimetizando o PRNT. De forma a definir um teste que proporcione melhor visualização do fenótipo de placa de lise, ou seja, que apresente qualidade na definição atrelado a diluição viral, diferentes condições analíticas foram analisadas: tipos de tampões para o controle de $\mathrm{pH}$, concentração da solução semi-sólida / CMC, tempo de incubação final, tempo de neutralização, e o tempo de adsorção e sedimentação celular. Posteriormente utilizando um painel sorológico contendo 126 soros pré e pósvacinais de crianças imunizadas com a vacina tríplice viral foi construída a curva ROC. Em seguida foram determinadas as faixas que melhor classificam os resultados dos soros testados (positivo, negativo ou indeterminado).

RESULTADOS As condições analíticas definidas foram: diluição viral para obtenção de aproximadamente 30 placas de lise/poço, bicarbonato de sódio como 
tampão no meio de cultura, meio semi-sólido 1,5\%, tempo de adsorção de 3 horas e tempo de incubação final de 4 dias. Com relação ao tempo de neutralização, duas horas se demonstrou mais adequada ao ensaio. A partir da construção da curva ROC foi definido um ponto de corte de 23 (reciproca da diluição). De acordo com o ponto de corte foram estabelecidas faixas interpretativas para o teste: negativo: $\leq 15-23$; indeterminado: > 23 - 50; positivo: > 50 (reciproca da diluição). Critérios de aceitação do teste foram estabelecidos para o controle viral (13 a 22) e para os soros controle (negativo: 19,26; positivo baixo: 96,11; positivo médio: 396,13; e positivo alto:1723,31).

CONCLUSÃO Este estudo promoveu melhoria na eficiência e eficácia da técnica.

PALAVRAS-CHAVE neutralização, caxumba, padronização, anticorpos. 